\title{
Coastal Water Quality Analysis for Brackish Water Aquaculture Development in Pasangkayu Regency
}

\author{
Firman $^{1}$, Nuddin Harahab ${ }^{2}$, Amin Setyo Leksono ${ }^{3}$, Hasnidar ${ }^{4}$ \\ \{firman.manizi@gmail.com¹, marmunnuddin@ub.ac.id², amin28@ub.ac.id ${ }^{3}$ \} \\ Universitas Brawijaya, Indonesia ${ }^{1,2,3}$ \\ Universitas Muslim Indonesia, Indonesia ${ }^{4}$
}

\begin{abstract}
West Sulawesi, precisely Pasangkayu Regency, is rich with coastal and marine resources, specifically from the brackish water aquaculture. This research arises from the negative growth in the palm oil plantation and processing industry sub-sector as the mainstay of GRDP of Pasangkayu Regency. At the same time, the development of brackish water aquaculture business has shown positive growth. The purpose of this research was to analyze the aquatic environment quality as the carrying capacity of brackish water aquaculture development. The sampling stations were in traditional, semi-intensive, and intensive aquaculture areas. The sampling points were at the main channel, primary channel and secondary channel. The data of this research were analyzed descriptively towards the results of laboratory analysis of water quality parameters. The results indicated that the coastal water quality in Tikke Raya District was highly suitable for brackish water aquaculture development as shown by the parameters consisting of temperature, Dissolved Oxygen (DO), salinity, pH, and Total Suspended Solid (TSS).
\end{abstract}

Keywords: Shrimp Culture, Carrying Capacity, Coastal Water Quality, Ponds.

\section{Introduction}

West Sulawesi, precisely Pasangkayu Regency, is rich with coastal and marine resources, specifically from the brackish water aquaculture, including tiger shrimp and milk fish [1].Tikke Raya Subdistrict is one of the areas in Pasangkayu Regency which has the most extensive coastal area, where a lot of fish cultivators live [2]. Brackish water aquaculture requires a physically, chemically, biologically, and ecologically suitable maintenance site to ensure the life of the commodities in cultivation.

The coastal area has to endure pressure and rapid environmental changes, following the aquaculture business. The rate of land use causes changes in its ecosystem, coastal typology, characteristics, and carrying capacity, as well as its potential [3]. Additionally, the coastal area functions as a transition for the terrestrial and marine ecosystems, with their own characteristics, and is sensitive to changes in the surrounding environmental conditions [4].

Increased population pressure and industrialization along the coastal area show that coastal waters are increasingly vulnerable to domestic waste, pesticides, toxic chemicals, which affect water quality [5]. According to [6] the main problem in coastal waters is high pollution affecting the quality of the aquatic environment. Organic and inorganic pollutants in coastal waters can compromise water quality, inducing degradation of biological functions, affecting the water 
condition. Water quality depends on the environment and is determined based on its physicochemical parameters [7].

The condition of coastal waters is actually vulnerable to contamination, for it is in the lowest position of a water flow. Thus, the development of brackish water aquaculture requires serious attention to water quality. This study aims to analyze the quality of the aquatic environment associated with the carrying capacity for the development of brackish water aquaculture.

\section{Method}

\subsection{Site and Duration of Research}

The site of research was the coastal area of Pasangkayu Regency, West Sulawesi Province, precisely in the coastal area of Tikke Raya Subdistrict. The study was conducted from March to December 2018.

\subsection{Research Design}

This study employed the survey method. According to [8] the survey method is an investigation conducted to obtain the facts of an existing symptom, and to look for factual information. This method explores problems to obtain justification for the situation and practices taking place.

\subsection{Determination of Sampling Station}

Biophysical data collection stations were divided into: (1) the three stations of pond cultivation area were grouped according to the technological aspect, including traditional, semiintensive and intensive, (2) the three waterway stations include the entrance of water in the pond, primary channels and secondary channels. Sampling and measurement at high and low tide were repeated for 2-3 times. Each observation location of the sampling point was marked for its geographical position with GPS.

\subsection{Data Analysis}

This research employed the descriptive analysis, as it aimed to describe the empirical and factual phenomena associated with water quality variables carefully and systematically. The measurement of water quality used several instruments purposefully selected to directly obtain results, and it was conducted by taking water samples for later analysis in the laboratory. The parameters of water quality measured are presented in Table 1.

Table 1. Water quality parameters and measurement instruments/methods

\begin{tabular}{clccc}
\hline No & Parameter & $\begin{array}{c}\text { Unit of } \\
\text { Measurement }\end{array}$ & $\begin{array}{c}\text { Measurement } \\
\text { Instruments/Methods }\end{array}$ & $\begin{array}{c}\text { Measurement } \\
\text { Site }\end{array}$ \\
\hline & Physical Parameter: & & & \\
\hline 1 & Temperature & $\left({ }^{\circ} \mathrm{C}\right)$ & Mercury thermometer & In situ \\
\hline 2 & TSS & $(\mathrm{ppm})$ & $\begin{array}{c}\text { Sample bottle and } \\
\text { cool box }\end{array}$ & Laboratory \\
\hline
\end{tabular}




\begin{tabular}{clccc}
\hline & Parameter Kimia: & - & pH-meter & In situ \\
\hline 1 & $\mathrm{pH}$ & $(\mathrm{ppt})$ & Refractometer & In situ \\
\hline 2 & Salinity & $(\mathrm{ppm})$ & DO Meter & In situ \\
\hline 3 & DO & $(\mathrm{ppm})$ & $\begin{array}{c}\text { Sample bottle, } \\
\text { Spectrophotometer }\end{array}$ & Laboratory \\
\hline 4 & Ammonia (NH3) & $(\mathrm{ppm})$ & $\begin{array}{c}\text { Sample bottle, } \\
\text { Spectrophotometer }\end{array}$ & Laboratory \\
\hline 5 & Nitrate (N02) & $(\mathrm{ppm})$ & $\begin{array}{c}\text { Sample bottle, } \\
\text { Spectrophotometer } \\
\text { Sample bottle, } \\
\text { Nitrite }(\mathrm{N03})\end{array}$ & Laboctrophotometer \\
\hline 7 & Phospate & $(\mathrm{ppm})$ & $\begin{array}{c}\text { BOD bottle, } \\
\text { Spectrophotometer } \\
\text { Sample bottle, }\end{array}$ & Laboratory \\
\hline 9 & COD & $(\mathrm{ppm})$ & $\begin{array}{c}\text { Saboratory } \\
\text { Spectrophotometer }\end{array}$ & Laboratory \\
\hline
\end{tabular}

\section{Results and Discussion}

\subsection{Ponds in Coastal Pasangkayu Regency}

Based on the research survey, the total area of ponds in Pasangkayu Regency's from 10 subdistricts was $3,948.18$ hectares, decreasing by 0.16 percent when compared to 2011 data of 4,723.73 hectares. A complete comparison of ponds area based on zoning plans for coastal areas and small islands of Pasangkayu Regency (RZWP3K) in 2011, with the result of the 2018 survey, are presented in Table 2.

Table 2. Comparison of Pond Land Area Based on RZWP3K Data and 2018 Survey Result

\begin{tabular}{rlrrrr}
\hline No & Subdistrict & $\begin{array}{c}\text { Total Area of } \\
\text { Pond in } \\
2015(\mathrm{Ha})\end{array}$ & $\begin{array}{c}\text { Total Area of } \\
\text { Pond based on } \\
\text { Survey in 2018 } \\
\text { (Ha) }\end{array}$ & Change (ha) & $\begin{array}{r}\text { Percentage } \\
(\%)\end{array}$ \\
\hline 1 & Sarjo & 310.194 & 259.31 & $(50.88)$ & $(0.16)$ \\
\hline 2 & Bambaira & 44.057 & 57.89 & 13.83 & 0.31 \\
\hline 3 & Bambalamotu & 82.157 & 81.91 & $(0.25)$ & $(0.00)$ \\
\hline 4 & Pasangkayu & 273.947 & 275.87 & 1.92 & 0.01 \\
\hline 5 & Pedongga & 649.205 & 564.24 & 84.97 & $(0.13)$ \\
\hline 6 & Tikke Raya & $1,049.214$ & $1,396.86$ & 347.65 & 0.33 \\
\hline 7 & Lariang & 920.636 & 142.03 & 776.61 & $(0.85)$ \\
\hline 8 & Baras & $1,010.496$ & 891.18 & 119.32 & $(0.12)$ \\
\hline 9 & Sarudu & 50.90 & 14.74 & 36.16 & $(0.71)$ \\
\hline 10 & Dapurang & 332.92 & 264.15 & 68.77 & $(0.21)$ \\
\hline & & $4,723.73$ & $3,948.18$ & $(775,55)$ & $(0.16)$ \\
\hline
\end{tabular}

Source: RZWP3K, 2011 and 2018 field survey result. 
Distribution of ponds on the coastal area of Pasangkayu Regency is illustrated in Figure 1.

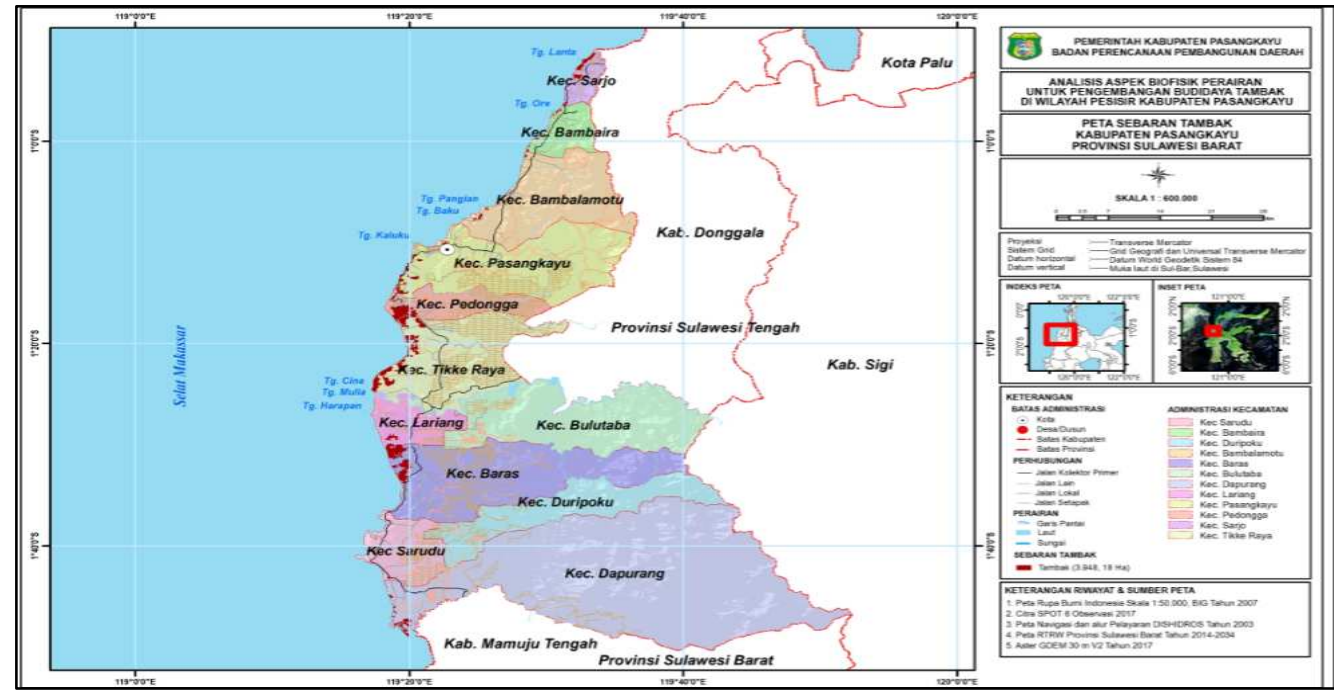

Fig. 1. Map of Ponds Distribution in the Coastal Area of Pasangkayu Regency.

The area of ponds in Tikke Raya Subdistrict based on RZWP3K documents in Pasangkayu Regency was set at 1,049.214 ha. Based on the result of the 2018 survey and spot image overlay in 2017 , the land area was of $1,396.86$ ha, increasing by 347.65 ha. The potential distribution of ponds in Tikke Raya Subdistrict of Pasangkayu Regency is presented in Figure 2.

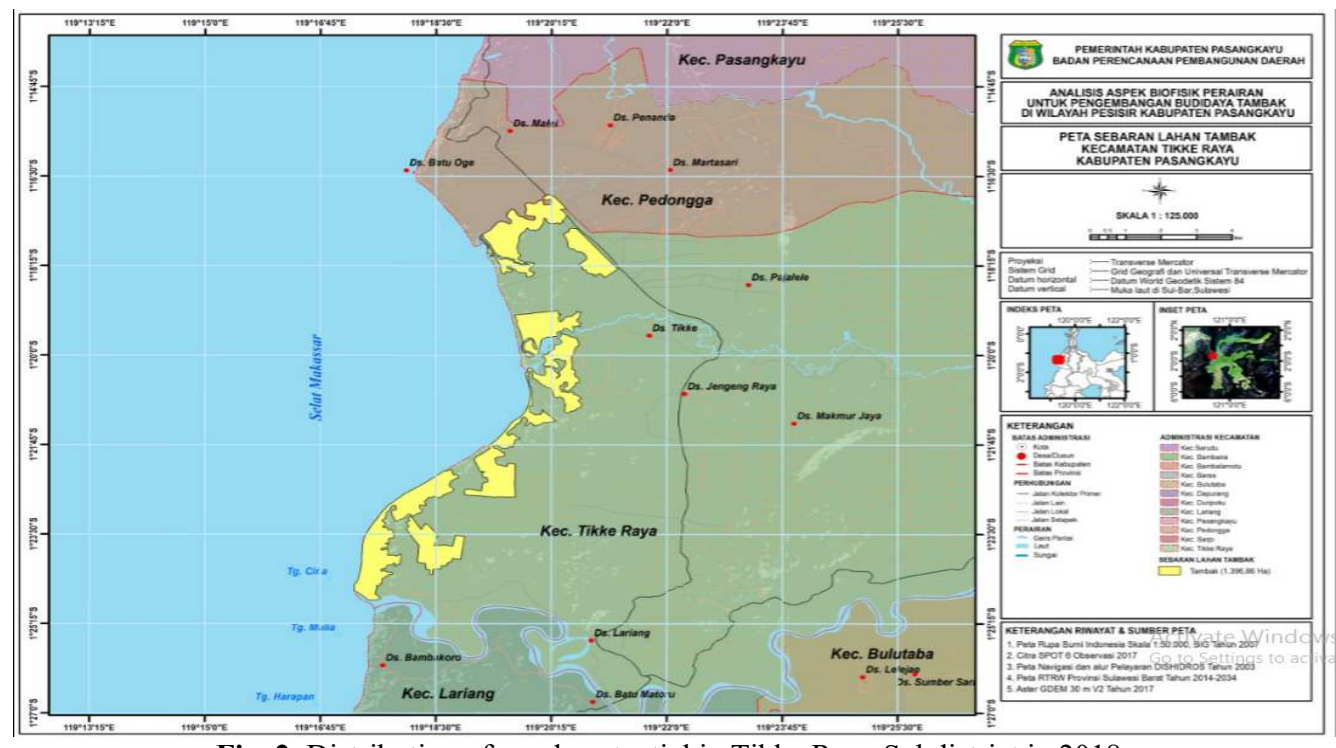

Fig. 2. Distribution of ponds potential in Tikke Raya Subdistrict in 2018. 


\subsection{Biological Conditions of Coastal Area}

\subsubsection{Plankton}

The result of the laboratory analysis identified the type of plankton found at the research site: Dactyliosolen sp; Rhabdonella elegana; Prorocentrum minimum; Eutreptia viridis; Schizomeris leibienil; Oscillatoria; Ankistrodesmus; and Aphanizomenon flos-aqu. It suggests that the plankton obtained shows a diversity value of 0.221 , uniformity value of 0.106 and dominance index of 0.455 .

Measurement of plankton is crucial in water quality observation for it is the first community in the food chain, serving as both a primary producer and a primary consumer. The abundance of phytoplankton is largely determined by the availability of nutrients, adequate light, and water movement. Phytoplankton play a role as the food for zooplankton and fish [9].

\subsubsection{Mangrove Ecosystem}

Mangrove ecosystems in Pasangkayu Regency were distributed in all coastal districts including in Tikke Raya. There were 7 types of mangroves found, including Rhizopora stylosa, Rhizopora mucronata, Avicennia alba, Sonneratia alba, Nypa fruticans, Bruguiera sp. and Ceriops sp. Rhizopora stylosa, Rhizopora mucronata, Avicennia alba were the dominant species with an extensive distribution, characterized by the dense, non-gummy leaf structure and the dominant green color on the leaf.

The advantages of the diverse mangrove ecosystems for the people render the mangrove ecosystem under a heavy ecological pressure, as it undergoes alterations for aquaculture and settlement purposes, resulting in reduced mangrove formations. The results of interpretation and ground check in July 2011 showed that the distribution of coastal vegetation, including true mangrove, associated mangrove, and non-mangrove vegetation, in Pasangkayu Regency was of 402.88 hectares (Table 3 ).

Table 3. Distribution and Area of Coastal Vegetation in the Coastal Pasangkayu Regency in 2011.

\begin{tabular}{|c|c|c|c|}
\hline No. & Subdistrict & Village & Total Area (Ha) \\
\hline \multirow{2}{*}{1} & \multirow{2}{*}{ Sarjo } & Sarude & 3.30 \\
\hline & & Letawa & 3.16 \\
\hline 2 & Bambalamotu & Pangiang & 15.55 \\
\hline 3 & Pasangkayu & Pasangkayu & 21.21 \\
\hline \multirow{2}{*}{4} & \multirow{2}{*}{ Tikke Raya } & Tikke & 6.95 \\
\hline & & Jengeng Raya & 40.46 \\
\hline \multirow{2}{*}{5} & \multirow{2}{*}{ Lariang } & Bambakoro & 86.20 \\
\hline & & Singgani & 35.76 \\
\hline \multirow{2}{*}{6} & \multirow{2}{*}{ Dapurang } & Sarasa & 22.70 \\
\hline & & Dapurang & 13.28 \\
\hline \multirow{4}{*}{7} & \multirow{3}{*}{ Sarudu } & Ako & 30.85 \\
\hline & & Sarudu & 92.66 \\
\hline & & Doda & 30.79 \\
\hline & & & 402.88 \\
\hline
\end{tabular}


Based on the data of the Forestry Agency of Pasangkayu Regency, mangrove density in all coastal area was classified as good (very dense) with a value of $>1,500$ trees/ha, except in the Lariang District, which has been included in the damaged category. The highest density level was in Tikke Raya Subdistrict, which was of 12,663 trees per hectare. The high level of mangrove density in Tikke Raya Subdistrict was due to the mangrove rehabilitation program held by ASTRA Corporation, in the collaboration with the local government of Pasangkayu Regency, especially the Forestry Agency, with Tikke and Jengeng Raya village selected as the sites of mangrove reforestation or rehabilitation.

\subsection{Water Quality Parameters}

Measurement of water quality in the coastal environment aims to determine the waters' suitability to the living needs of aquatic biota, especially shrimps, and to determine the carrying capacity for the development of shrimp culture. Parameters of water quality include temperature, dissolved oxygen (DO), salinity and others.

\subsubsection{Water Temperature}

Temperature affects the survival of fishes, including their eggs, larvae, seeds, and adult form. The temperature of the maintenance media shall affect the development of larvae from eggs, for it also affects the rate of absorption of the yolk as the source of energy for metabolic processes of the larvae. According to Kamler, Szlamińska [10], temperature impacts the metabolic rate of aquatic animals. Also stated by Avault (1985) in [11], that water temperature affects the activity of fish feeding.

Pramono and Marnani [12] suggests that the rapid increase in larval length in the initial phase depends on the rate of absorption of the yolk. Significantly low water temperature may result in a slow metabolic process, affecting the growth rate of fish larvae to become slower.

According to Kurniawan [13], the rate of absorption of the yolk increases as temperature increases. Temperature impacts larval survival significantly. Affirmed by Sriharti [11], low temperatures shall affect larval metabolism and food digestion. Furthermore, high temperature fluctuation may reduce fish larvae feeding activity. When the temperature needed by the larvae is not in accordance with its growth and development rate, the physiology of the larvae might be affected, especially their metabolism. The larvae shall refuse to digest the available food sources in the body, which will stunt their growth over time, causing their diminishing life endurance [11].

\subsubsection{Dissolved Oxygen (DO)}

The result of DO measurement at the three stations of the observation site suggested a value range including $4.9 \mathrm{mg} / \mathrm{L} ; 5.1 \mathrm{mg} / \mathrm{L}$ and $5.5 \mathrm{mg} / \mathrm{L}$. This value is still within the threshold of quality standard of sea water for marine life, with a dissolved oxygen content of $>5 \mathrm{mg} / \mathrm{L}$ [14]. The level of dissolved oxygen in natural waters varies, depending on temperature, salinity, water turbulence, and atmospheric pressure. The greater the temperature and altitude and the lower the atmospheric pressure, the lower the level of dissolved oxygen [15]. Dissolved oxygen level fluctuates daily (diurnal) and seasonally, depending on the mixing and movement (turbulence) of water masses, photosynthetic activity, respiration and the amount of waste entering the water [16]. 
Fish and other aquatic organisms need large amounts of dissolved oxygen. This oxygen demand varies among organisms. The presence of excessive metal in the waters will affect the respiratory system of aquatic organisms. When dissolved oxygen level is low and metal is present in a high concentration, aquatic organisms are seriously afflicted [16].

\subsection{3 pH}

Water acidity (water $\mathrm{pH}$ ) is a value that shows the activity of hydrogen ions in water (Sanusi and Putranto, 2009). The $\mathrm{pH}$ value of 7 is neutral, $>7$ is alkaline, and $<7$ is acidic. Aquatic biota is mostly sensitive to changes in $\mathrm{pH}$ and likes a $\mathrm{pH}$ value of between 7-8.5 [16].

The $\mathrm{pH}$ value in a body of water has a great impact on aquatic organisms thus functions as a clue to state the pros and cons of the water condition. Usually, it can be used as an indicator of the balance of chemical elements, and can affect the availability of chemical elements and nutrients highly beneficial for aquatic vegetation. High or low $\mathrm{pH}$ is affected by fluctuations in $\mathrm{O} 2$ and $\mathrm{CO} 2$ content. Not all creatures can withstand changes in $\mathrm{pH}$ values, and the nature has provided a unique mechanism to eliminated or minimize changes. Changes in $\mathrm{pH}$ can have a devastating effect on marine life, both directly and indirectly. The direct result is the death of fish, and it reduces primary productivity. Indirect effects include changes in the toxicity of substances present in water. According to [17], the $\mathrm{pH}$ value between 6.5-8.0 is a safe limit for the life of aquatic biota in it.

\subsubsection{Salinity}

Salinity is the concentration of all salt solutions contained in seawater, and it affects the osmotic pressure of water. The higher the salinity, the greater the osmotic pressure [18]. Differences in water salinity is due to differences in evaporation and precipitation.

Salinity indicates the amount of salt dissolved in water. Good salinity level for aquaculture in ponds ranges from 7-30 per mil (optimally 15-25 per mil). 1 per mil $=1$ ppt (parts per thousand). However, shrimps can still be maintained at lower salinity up to $0.5 \mathrm{ppt}$ and at higher salinity up to $50 \mathrm{ppt}$, despite the decreasing rate growth. Salinity affects the osmose regulation process in all water organisms. It also affects other water quality parameters such as oxygen solubility, nitrite and ammonia toxicity.

\subsubsection{Total Suspendid Solid (TSS)}

Total Suspended Solid (TSS) includes substances suspended (diameter $>1 \mu \mathrm{m}$ ) retained in the Millipore filter with a pore diameter of $0,45 \mu \mathrm{m}$ [16]. TSS include mud and fine sand, and microorganisms, which are mainly caused by soil erosion carried into a body of water.

The high TSS level is due to settlement, agriculture, plantation activities, and the pond activity itself. It might reduce the availability of light in the water column that is needed by marine biota, such as phytoplankton and seagrass. In addition, it might negatively affect fish and zooplankton, since the biota gills are blocked by suspended particles, interfering with their respiratory process.

Supported by the results of previous studies, when suspended substances in the water inhibit light penetration to the surface of the water, it reduces the intensity of light needed by phytoplankton. The standard TSS level for aquaculture is $(80 \mathrm{mg} / \mathrm{L})$. If it exceeds the standard, then the waters are not suitable for aquaculture [19]. 


\subsubsection{BOD}

Biologycal Oxygen Demand (BOD) describes the level of organic substances, including the amount of oxygen needed by aerobic microbes to process organic substances into carbon dioxide and water [20]. The standard quality for marine biota is of a value of $20 \mathrm{mgl} / \mathrm{L}$ (KLH No.51 of 2004). BOD only describes organic material that can be decomposed biologically (biodegradable), resulting from the decay of died plants and animals, and from domestic and industrial waste [16].

Biochemical Oxygen Demand (BOD) is a characteristic indicating the amount of dissolved oxygen needed by microorganisms to break down or decompose organic material under aerobic conditions. BOD is an index number for measuring pollutants from waste entering the waters. The greater the BOD concentration, the higher the concentration of organic material in the water [21].

Increased level of BOD can reduce the concentration of dissolved oxygen in a body of water, negatively affecting the life of aquatic biota. When the concentration of dissolved oxygen falls below $5 \mathrm{mg} / \mathrm{L}$, biota that has a low tolerance for changes in the oxygen level can become stressed, leading to its death. The lower the oxygen concentration, the greater the stress. Furthermore, species that are sensitive to low level of dissolved oxygen shall be replaced by species that are more tolerant of this condition, and this might significantly reduce the diversity of aquatic biota species.

BOD parameters include aspects that can be used to determine the level of water pollution. Based on the pollution level criteria of the BOD value, the waters of Tikke Raya are classified as a low to high pollution. The higher concentration of BOD indicates that the watershed has been polluted, while the low BOD concentration can be categorized as good waters. The level of pollution is low if the BOD value is between $0-10 \mathrm{mg} / \mathrm{l}$, whereas the level of pollution is moderate if the BOD value is between $10-20 \mathrm{mg} / \mathrm{l}$ [22].

\subsubsection{COD}

According to Wardhana [23], COD (Chemical Oxygen Demand) describes the amount of oxygen (mg) needed to oxidize the total organic substances contained in 1 liter of a water sample. COD concentration obtained in the research site ranged from $65.49 \mathrm{mg} / \mathrm{L} ; 53.47 \mathrm{mg} / \mathrm{L}$; and $77,493 \mathrm{mg} / \mathrm{L}$. COD describes the total amount of oxygen needed to chemically oxidize organic material, both the biodegradable and non-biodegradable ones, into $\mathrm{CO} 2$ and $\mathrm{H} 2 \mathrm{O}$ [16]. These materials can be in the form of detergents or oil from industrial activities and surrounding settlement activities. COD is generally greater than BOD, because the level of chemical compounds that can be oxidized chemically is greater than that of biological oxidation [24].

Furthermore, high COD level is considered a disturbance in fisheries and agriculture activities. If COD exceeds the quality standard, the lower the oxygen content in water. The low level of dissolved oxygen adversely affects the life of fish and other aquatic biotas. Anaerobic conditions shall occur, with foul odors and aesthetic problems, when there is no identifiable level of dissolved oxygen at all [25].

\subsubsection{NO2}

Nitrates obtained from the three stations sampling went through a laboratory analysis, resulting in a range of values of $0.021 \mathrm{mg} / \mathrm{L}$ was obtained; $0.0341 \mathrm{mg} / \mathrm{L}$ and $0.1146 \mathrm{mg} / \mathrm{L}$. The nitrate concentration exceeds the threshold of the quality standard for marine biota, which is 
$0.008 \mathrm{mg} / \mathrm{L}$ [14]. This condition is due to the excessive influx of waste originating from agricultural and settlements activities from the mainland through the river. According to Supriharyono [26], estuary is a nutrient trapping area. Mixing currents of sea water and river water allows trapping nutrients in the estuary area. Nitrate is the main form of nitrogen in natural waters, and is the main nutrient for plant and algae growth [16].

This condition is highly dangerous to marine biota, because according to Effendi (2003), nitrate-nitrogen concentrations of more than $0.2 \mathrm{mg} / \mathrm{l}$ can cause eutrophication of the waters, and shall further stimulate the growth of algae and aquatic plants rapidly (blooming). This might result in decreased phytoplankton diversity since the domination of one or more specific species. The increase in the amount of phytoplankton contained in the water column escalates oxygen consumption, hence the decrease in the oxygen content in the waters. The organic material originating from phytoplankton blooming, and waste from both household and industrial activities in estuarine waters, then settle and are trapped in sediment. If they exceeed the acceptable level, a decrease in oxygen content might occur, as the bacteria use it for respiration in its overhaul. In anaerobic conditions, the process of decomposition of organic materials can produce toxic ammonia, methane and hydrogen sulfide compounds. The reduced oxygen content in the waters and the toxic compounds produced can cause the death of fish and living macrozoobenthos.

\subsubsection{NO3}

Nitrites obtained from the three-stations sampling went through a laboratory analysis, resulting in the values of $1.7694 \mathrm{mg} / \mathrm{L} ; 2.085 \mathrm{mg} / \mathrm{L}$; and $3.0939 \mathrm{mg} / \mathrm{L}$. Nitrite level of more than $0.05 \mathrm{mg} / \mathrm{L}$ can become toxic to highly sensitive aquatic organisms [27]. Generally, the concentration of nitrite obtained from the sampling was more than $0.05 \mathrm{mg} / \mathrm{L}$. Natural water nitrite is usually found in a very low level and is less than nitrates, since they are unstable in the presence of oxygen [16]. Nitrite is an intermediate form between ammonia and nitrate (nitrification), and between nitrate and nitrogen gas (denitrification) [16].

If nitrite is absorbed by fish, it will react with hemoglobin to form methemoglobin. Given that methemoglobin cannot function as an oxygen carrier, continuous absorption of nitrite can cause hypoxia and cyanosis. Blood containing methemoglobin will turn brown; thus, nitrite poisoning in fish is often called brown blood [28].

\subsubsection{Phosphate}

Phosphate is a form of phosphorus that can be beneficial for aquatic plants (Dugan, 1972). Phosphate concentration obtained from the sampling was tested in the laboratory, obtaining a range of values of $<0.01 \mathrm{mg} / \mathrm{L}$; and $0.37 \mathrm{mg} / \mathrm{L}$. The obtained phosphate concentration exceeded the quality standard set for marine biota, which is $0.015 \mathrm{mg} / \mathrm{L} \mathrm{[14]}$. Phosphate (PO4) is a form of phosphorus that can be directly beneficial for phytoplankton [16].

These compounds are generally sourced from industrial pollution, agricultural fertilizer runoff, domestic waste and organic decay. Phosphate is produced through the process of breaking down organic phosphorus by bacteria from decaying tissues. Runoff from agricultural areas that use fertilizer contributes substantially to the presence of phosphorus. The presence of excessive phosphorus accompanied by the presence of nitrogen can stimulate the explosion of algae growth in waters [16]. 


\subsubsection{Pb, Cd dan $\mathrm{Hg}$}

Environmental pollution is known to be caused by pollutants containing life-threatening metals, both direct to aquatic ecosystems and indirectly to humans. The existence of metals in the aquatic environment must be tested for its level in the body of the water and in the organisms inhabiting it. Therefore, the testing of metal content in this study includes the water, the sediments, and the fish.

Laboratory analysis result from the sampling obtained a range of values of $\mathrm{Pb}$ of $<0.002$; $0.2809 ; 0.2859, \mathrm{Cd}$ of $<0.003 ; 0.0823$ and 0.1144 , and $\mathrm{Hg}$ of $<0.0003$ Syaifullah [29] states that the minimum threshold for caddium (Cd) set by ANZECC is $10 \mathrm{mg} \mathrm{kg}-1, \mathrm{Hg}$ quality standard set by ANZECC is $1 \mathrm{mg} \mathrm{kg}-1$ and $\mathrm{Pb}$ quality standard set by ANZECC is $50 \mathrm{mg} / \mathrm{kg}-1$.

The presence of metals in a body of water may originate from natural sources, including erosion of mineral stones, metal particles in the air and daily activities of the people in the form of industrial or household waste [30]. Metals accumulate naturally in waters in a very low level, but it can increase due to anthropogenic pollutants at any time which can affect aquatic biota and pose a risk to the consumers.

\subsubsection{Alkalinity}

Alkalinity is an aquatic chemical parameter indicating the amount of carbonate and bicarbonate ions binding the alkaline earth metal in freshwater. This illustrates the capacity of water to neutralize acid, or is also commonly interpreted as a buffer capacity for changes in $\mathrm{pH}$. Waters containing alkalinity of $\geq 20 \mathrm{ppm}$ indicate that they are relatively stable against acid/base changes, thus the buffer or base capacity is more stable. Besides being dependent on $\mathrm{pH}$, alkalinity is also affected by mineral composition, temperature, and ionic strength. The level of natural alkalinity never exceeds $500 \mathrm{mg} /$ liter of $\mathrm{CaCO} 3$. Waters with too high alkalinity are not very suitable for aquatic organisms, because they are usually followed by high hardness level or high sodium salt level.

Alkalinity concentration obtained from the sampling suggested a range of value of $8.81 \mathrm{ppm}$; $46.2525 \mathrm{ppm}$ and $104.619 \mathrm{ppm}$. Boyd, Massaut [31] recommends a range of alkalinity and hardness for fish of 20 to $300 \mathrm{ppm}$. Optimal alkalinity for intensive fish culture is 100 to 150 ppm. Alkalinity and hardness, in addition to functioning as a buffer of $\mathrm{pH}$, is also important in maintaining the sensitivity of cell membranes in nerve and muscle tissue through its calcium content [32].

The growth of every organism, including fish, is supported by two opposite processes. One process tends to decrease the body's energy (catabolism), while the other process tends to increase the body's energy (anabolism) [33]. Growth occurs when there is an excess of energy input and amino acids (protein) derived from food. Before being used for growth, energy is used to fulfill all activities and maintenance of the body through metabolic processes. Although growth does not occupy the last priority in the distribution of energy, in reality, growth and reproduction are seen to get only the remaining energy after all other functions, including responses to stress and others. Thus, growth and reproduction are the right indicators to see if a fish succeeds in dealing with environmental problems.

\subsubsection{NH3}

According to the Environmental Quality Standard Guidelines of the Secretary of the State Minister for Population and the Environment (1988), it is determined that the maximum level 
of N-NH3 in freshwater fish culture is $0.016 \mathrm{mg} / \mathrm{l}$. As for sea water fish culture, the allowed $\mathrm{NH} 3$ level is $1.0 \mathrm{mg} / \mathrm{l}$ or less, and the desirable value is $0.3 \mathrm{mg} / \mathrm{l}$ or less. However, experts recommend conducting further research on acceptable level of ammonia for various types of aquaculture.

According to Umroh [34], ammonia is crucial in aquaculture in the form of ammonium. It can be utilized by aquatic plants through the process of assimilation, and be used as an energy source by nitrifying microorganisms in the oxidation of ammonia into NO2, and then into NO3.

According to Yudha (2009) in Silaban and Santoso [35], fish cannot tolerate ammonia in a very high concentration as it can interfere with the binding process of oxygen by the blood, and can ultimately lead to death. Ammonia is toxic in a high concentration since it can poison the culture organism. Its accumulation in aquaculture media is one of the causes of water quality degradation, which can result in the failure of crab culture production [36].

\subsubsection{Total Coliform}

Total Coliform obtained from the sampling was in the range of values of $<1.8$ and 23 MPN/100mL. All observation sites showed that they did not exceed the established quality standard, which is $1000 \mathrm{MPN} / 100 \mathrm{~mL}$. The low Total Coliform was due to the sampling site being far from residential areas. The type of microorganism that greatly affected water quality is the Escherichia coli bacteria. This bacterium is classified as coliform, and lives normally in human or animal feces, hence the name of fecal coliforms [37].

Escherichia coli is originally known as Bacterium coli. This bacterium is abundant in the human and animal blood vessels. Colifekal is a coli bacterium in the feces of humans and mammals. These bacteria can enter the water if there is fecal waste in the body of water, suggesting that the substances can become toxic to plankton. The presence of colifecal bacteria in the water indicates that the waters may be polluted. They cannot be used as a source of drinking water [38]. The water quality measurement of all the parameters is presented in Table 4.

Table 4. Result of Measurement of Coastal Water Quality Parameters in Tikke Raya Subdistrict

\begin{tabular}{llrrrr}
\hline \multirow{2}{*}{ No } & \multirow{2}{*}{ Water Quality } & \multicolumn{3}{c}{ Sampling Station } & \multicolumn{2}{c}{$\begin{array}{c}\text { Standard Value for } \\
\text { Marine Life }\end{array}$} \\
\cline { 3 - 6 } 1 & Water quality & 29.5 & 31.9 & 30.3 & $28-30$ \\
\hline 2 & DO & 4.9 & 5.1 & 5.5 & $>4.0$ \\
\hline 3 & pH & 6.85 & 7.44 & 5.85 & $7.5-8.5$ \\
\hline 4 & Salinity & 23 & 29 & 4 & $26-32$ \\
\hline 5 & TSS & 12 & 7 & 626 & $20 \mathrm{mg} / \mathrm{L}$ \\
\hline 6 & BOD & 29.066 & 21.72 & 12.658 & $20 \mathrm{mgl} / \mathrm{L}$ \\
\hline 7 & COD & 77.493 & 53.47 & 65.49 & 100 \\
\hline 8 & NO2 & 0.037 & 0.009 & 2.4098 & 0.5 \\
\hline 9 & NO3 & 5.5545 & 1.7891 & 3.4226 & $<0.05 \mathrm{mg} / \mathrm{L}$. \\
\hline 10 & Phosphate & 0.3704 & $<0.01$ & $<0.01$ & $0.1-5$ \\
\hline 11 & Pb & 0.2809 & $<0.002$ & 0.2859 & 0.03 \\
\hline 12 & Cd & 0.1144 & 0.0823 & $<0.003$ & 0.01 \\
\hline 13 & Hg & $<0.0003$ & $<0.0003$ & $<0.0003$ & 0.002 \\
\hline 14 & Alkalinity & 46.2525 & 104.619 & 8.81 & $100-150$ \\
\hline 15 & NH3 & 1.0385 & 0.7048 & 1.2774 & $\leq 0.01$ \\
\hline
\end{tabular}




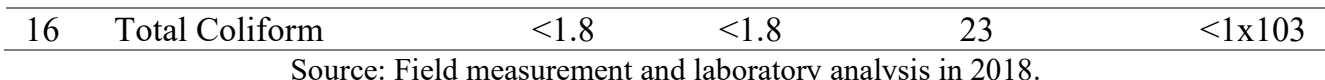

Based on the results of the analysis of water quality, it is considered appropriate for brackish water aquaculture or shrimp cultivation. However, the development of shrimps in the pond must be regulated properly, especially with regard to the drainage system or pond water input and output channels, to avoid water quality degradation in the coastal environment. The development of aquaculture should also include an analysis of the level of land suitability with the technology used, either in an intensive, semi-intensive, or traditional system of cultivation.

\section{Conclusion}

The quality of coastal waters in the Tikke Raya Subdistrict was good and suitable for brackish water aquaculture. This was in accordance with the result of the analysis, suggesting that the level of some water parameters were in accordance with the quality standard. Parameters that were in accordance with the quality standards included Temperature, DO, $\mathrm{pH}, \mathrm{BOD}, \mathrm{COD}$, $\mathrm{Pb}, \mathrm{Cd}, \mathrm{Hg}$, total Coliform, Alkalinity, and NH3. The coastal area of Tikke Raya sub-district is very suitable for the development of fish farming.

\subsection{Suggestion}

To anticipate the degradation of water quality, the local government, the farmers, and the society must always protect the coastal environment. Companies involved are required to manage the waste properly to avoid polluting the aquatic environment.

\section{References}

[1] Mustafa, A., E. Ratnawati, and I. Sapo, Penentuan Faktor Pengelolaan Tambak yang Mempengaruhi Produktivitas Tambak Kabupaten Mamuju, Provinsi Sulawesi Barat [Determining Of Brackishwater Pond Management Factors That Effect On The Brackishwater Pond Productivity In Mamuju Regency, West Sulawesi Province]. Jurnal Ilmiah Perikanan dan Kelautan, 2010. 2(2): p. 199-207.

[2] Hanafi, M. and L. Arifin, Struktur Geologi di Perairan Pasang Kayu, Sulawesi Barat. Jurnal Geologi Kelautan, 2016. 8(3): p. 119-125.

[3] Utojo, et al., Penentuan Lokasi Pengembangan Budidaya Tambak Berkelanjutan dengan Aplikasi Sistem Informasi Geografis di Kabupaten Lampung Selatan. Jurnal Riset Akuakultur, 2016. 4(3): p. 407-423.

[4] Yuniarto, B., Membangun Kesadaran Warga Negara dalam Pelestarian Lingkungan. 2013: Deepublish.

[5] Thorne-Miller, B., The living ocean: understanding and protecting marine biodiversity. 1999: Island Press.

[6] Harahap, N., A. Soeprijanto, and R. Lestari, The effect of soil quality on the survival rate of mangrove vegetation. J. Eng. Appl. Sci, 2015. 10: p. 154-156.

[7] Hamuna, B., R.H.P. Tanjung, and M.H. Suwito, Study of sea water quality and pollution index based on physical-chemical parameters in Depapre District waters, Jayapura. Jurnal Ilmu Lingkungan, 16(1), 35-43, 2018.

[8] Nazir, M., Metode Penelitian Cetakan Kelima. Jakarta: Ghalia Indonesia, 2003. 
[9] Champalbert, G., et al., Relationships between meso-and macro-zooplankton communities and hydrology in the Senegal River Estuary. Estuarine, Coastal and Shelf Science, 2007. 74(3): p. 381-394.

[10] Kamler, E., et al., Temperature-induced changes of early development and yolk utilization in the African catfish Clarias gariepinus. Journal of Fish Biology, 1994. 44(2): p. 311-326.

[11] Sriharti, Pengaruh suhu terhadap penetasan telur, pertumbuhan dan daya tahan hidup larva ikan bandeng (Dicentranchus labrax L.) Seminar biologi XV. Bandar Lampung: 872-876., 1997.

[12] Pramono, T.B. and S. Marnani, Pola Penyerapan Kuning Telur dan Perkembangan Organogenesis pada Stadia Awal Larva Ikan Brek (Puntius orphoides). 2006.

[13] Kurniawan, A., Identifikasi Kualitas Air Berdasarkan Nilai Resistivitas Air, Vol. 3, No.6. Ekuilibrium, hal 46-49, 2012.

[14] KLH, Kepmen LH No. 51 Tahun 2004 Tentang Baku Mutu Air Laut. 2004.

[15] Jeffries, M. and D. Mills, Freshwater Ecology, Principles and Aplication. Jhon wiley and sons. Chishester. UK. 285p, 1996.

[16] Effendi, H., Telaah kualitas air, bagi pengelolaan sumber daya dan lingkungan perairan. 2003: Kanisius.

[17] Odum, E.P., Ecology, the link between the natural and the social sciences. 1975: Oxford and IBH Publishing.

[18] Widiadmoko, W., Pemantauan Kualitas Air Secara Fisika dan Kimia di Perairan Teluk Hurun. Balai Besar Pengembangan Budidaya Laut (BBPBL) Lampung. Politeknik Negeri Lampung. Bandar Lampung, 2013.

[19] Iswanto, C.Y., S. Hutabarat, and P.W. Purnomo, Analisis Kesuburan Perairan Berdasarkan Keanekaragaman Plankton, Nitrat dan Fosfat di Sungai Jali dan Sungai Lereng Desa Keburuhan, Purworejo. Management of Aquatic Resources Journal, 2015. 4(3): p. 84-90.

[20] Davis, M.L. and D. Cornwell, Introduction to Environmental Engineering (McGraw Hill). Inc., New York, 1991.

[21] Yudo, S., Kondisi Kualitas Air Sungai Ciliwung di Wilayah DKI Jakarta Ditinjau Dari Paramater Organik, Amoniak, Fosfat, Deterjen Dan Bakteri Coli. Jurnal Air Indonesia, 2018. 6(1).

[22] Salmin, O.T., dan Kebutuhan Oksigen Biologi (BOD) Sebagai Salah Satu Indikator Untuk Menentukan Kualitas Perairan. Pusat Penelitian Oseanogafi-Lipi, Jakarta, 2005.

[23] Wardhana, W.A., Dampak Pencemaran Lingkungan (Edisi Revisi). Yogyakarta: Penerbit Andi, 2004.

[24] Achmad, R., Kimia Lingkungan. Andi Press. Yogyakarta. , 2004.

[25] Azwir, Analisa Pencemaran Air Sungai Tapung Kiri oleh Limbah Industri Kelapa Sawit PT. Peputra Masterindo di Kabupaten Kampar, 2006, Program Pascasarjana Universitas Diponegoro.

[26] Supriharyono, S., The Problems of Coastal and Marine Resources Management in Indonesia. Journal of Coastal Zone Management, 2000. 4(1): p. 41-49.

[27] Moore, J.W., Inorganic Contaminant of Surface Water. Springer-Verlag, New York. 334 p., 1991.

[28] Rahayuningsih, M. and R.J.E.d.K.I.d.U.D. Purnawati, Perbaikan Konversi Mikrobial Inulin Menjadi Fruktosa. didalamSusdiana, Y. 1997. 1993.

[29] Syaifullah, M., Kandungan Logam Non Esensial (Pb, Cd Dan Hg) Dan Logam Esensial (Cu, Cr dan Zn) Pada Sedimen di Perairan Tuban Gresik dan Sampang Jawa Timur. Jurnal Kelautan: Indonesian Journal of Marine Science Technology, 2018. 11(1): p. 69-74.

[30] Palar, H., Pencemaran dan toksikologi logam berat, 1994, Jakarta: Rineka Cipta.

[31] Boyd, C., L. Massaut, and L. Weddig, Procedures to lessen the environmental impacts of pond aquaculture. INFOFISH International, 1998. 2(98): p. 27-33.

[32] Smith, L., Introduction to Fish Physiology-TFH Publ. Inc. Neptune City, 1982.

[33] Zonneveld, N., E. Huisman, and J. Boon, Prinsip-prinsip budidaya ikan. 1991: PT Gramedia Pustaka Utama. 
[34] Umroh, Pemanfaatan Konsorsia Mikroorganisme Sebagai Agen Bioremediasi Untuk Mereduksi Amonia Pada Media Pemeliharaan Udang Windu (Penaeus monodon Fabricius). Akuatik: Jurnal Sumberdaya Perairan, 2007. 1(1): p. 15-20.

[35] Silaban, T.F. and L. Santoso, Pengaruh Penambahan Zeolit Dalam Peningkatan Kinerja Filter Air Untuk Menurunkan Konsentrasi Amoniak Pada Pemeliharaan Ikan Mas (Cyprinus Carpio). e-Jurnal Rekayasa dan Teknologi Budidaya Perairan, 2012. 1(1): p. 47-56.

[36] Fauzzia, M., I. Rahmawati, and I.N. Widiasa, Penyisihan Amoniak dan kekeruhan pada Sistem Resirkulasi Budidaya Kepiting dengan Teknologi Membran Biofilter. Jurnal Teknologi Kimia dan Industri, 2013: p. 155-161.

[37] Saeni, M.S., Kimia Lingkungan. Bahan Pengajaran Pusat Antar Universitas. Institut Pertanian Bogor, Direktorat Jendral Pendidikan Tinggi, Departemen Pendidikan dan Kebudayaan, 1989. 151.

[38] Sastrawijaya, T., Pencemaran Lingkungan, Rineka Cipta, 2000, Jakarta. 